\title{
Biology for linguists: An obstacle or a royal path to concept building?
}

\author{
Patrick Sériot \\ University of St. Petersburg \\ Russia \\ e-mail: patrick@seriot.ch
}

\begin{abstract}
Exchanging models, metaphors and analogies between biology and linguistics is well known, and August Schleicher's book Die Darwinsche Theorie und die Sprachwissenschaft (1863) is a typical work in this line of thought. Nonetheless, there is a "counter-mainstream" to this, which is less well known, but extremely interesting to follow: orthogenesis, an explicitly anti-Darwinian theory in biology, the consequences of which are fascinating to observe in the history of ideas in Soviet linguistics as well as in Russian émigré linguistics in the inter-war period. Here the names of Nikolaj Troubetzkoy and Roman Jakobson are of primary importance if we consider that they received most of their inspiration from Goethe's 'morphology' ('Formenlehre') and Lev Berg's 'nomogenesis'. The discussion between Georges Cuvier and Étienne Geoffroy Saint-Hilaire in 1830 is also an important landmark to highlight the specificity of a Russian and Central European structuralism which is extremely different from Saussure's.
\end{abstract}

Keywords: morphology; nomogenesis; structuralism; Roman Jakobson

In this short paper, I would like to give a brief account of a work in progress, with a double question: what is the role of biological metaphors in linguistics, and what sort of linguistics is involved in the biological controversies of the two preceding centuries?

When reading the index of Roman Jakobson's Selected Writings one can find unexpected names of Romantic philosophers (Johann Wolfgang von Goethe), slavophile grammarians (Konstantin Aksakov) and anti-Darwinian biologists (Karl Ernst von Baer, Lev Berg), appearing mainly in his inter-war writings. If we admit that these references are not fortuitous, their abundance and regularity deserve to be taken into account and closely scrutinized. Jakobson, in his texts in Russian and Czech, but also, though less explicitly, in German and French, refers to a scientific 
world now forgotten in the French-speaking intellectual area, embodied in the form of an alternative to Darwinism.

It appears that a great number of Jakobson's leitmotifs (e.g. the denial of randomness in evolution, the typological obsession, the notions of preformation, of tendency of evolution, of teleology, of convergence of languages, of taking into account the "space factor") remained incomprehensible for commentators like Georges Mounin or even André Martinet. These take on their full meaning, however, if we read them in the light of philosophical and scientific currents of thought which, availing themselves of the German Naturphilosophie, claimed an explicit and militant rejection of Darwinism and "positivism" throughout the 19th century.

Jakobson's interest in the major issues of the German romantic episteme, and in the positions and discoveries of Slavophile linguistics, is not isolated. It can be found at various times, to a greater or lesser degree, in inter-war Soviet linguistics, in different complex configurations, where declared enemies, professing antithetic scientific principles (Marr/ Vinogradov) or researchers working in pure mutual ignorance (Bakhtin/Lysenko) can find themselves paradoxically united around the same thematic units.

Therefore Jakobson can be read as an introduction to Russian scientific culture.

Through these unexpected combinations however, we will ask two questions of an epistemological order:

(i) how are the relationships between natural and human sciences organized?

(ii) how are relations between time and space organized in the history of the human sciences?

We shall first review the general themes of anti-Darwinism in Russia, and then the theme of form and type.

\section{Anti-darwinism, an anti-positivist programme}

Jakobson's texts of the years 1920-1930 sound as a denial, which can be summarized as the formula: "no to positivism". This is a paradigm shift declared and repeated at length. But is it enough to proclaim a rupture for it to be effective? Distinguishing oneself from something is, to a certain extent, always dependent on it.

The role played by the biologist Lev Berg's book Nomogenesis in the thinking of Jakobson ${ }^{1}$ or Olga Frejdenberg ${ }^{2}$ is becoming apparent. Berg resolutely refutes what he thinks is an essential trait of Darwinism: the idea of evolution not directed towards a

1 "I read passionately Berg's book on Nomogenesis" (R. Jakobson, letter to B. Shklovskij, 26 Feb. 1929, in Toman 1994: 61).

2 "I was passionate about reading Berg's Nomogenesis. [...] I found in this book the proofs in support of all my secret anti-Darwinism" (Frejdenberg, quoted in Braginskaya 1998: 750; cf. also Velmezova 2003). 
goal, i.e. of random evolution. His book tries to explain all evolution of living beings by the idea of law (in Greek nomos): nomogenesis (Cf. Sériot 2014: 181-182). But we must recall the existence of another contemporary of Jakobson: Aleksandr A. Lyubishchev (1890-1972), another convinced anti-Darwinist, whose thought offers a particularly illuminating light on the counter-programme.

This biologist of an encyclopaedic knowledge was an entomologist specializing in systematics and the history of science. He sought to construct a theory that would make predictions comparable to those of the missing chemical elements in Mendeleev's periodic table. Like Berg, he refused the idea of chance and proposed an explanation of the living phenomena based on the idea of finality, or conformity to a goal. However, he insisted even more on the idea of the order of the world, founded on laws of constitution of forms in the absence of any genealogical relation between them. If Darwin postulated that the resemblances between two species can be explained only by a common ancestry, and if Berg explained the similarities by convergence, Lyubishchev was interested in similarities founded on the laws of forms. For him, the classification of species, or systematics, must not be related to phylogeny, i.e. to the history of their origin. Lyubishchev is undoubtedly the scholar who presents the counter-programme in the most systematic way by a series of dichotomies whose second term is axiologically privileged: mechanicism/organicism; merism (the parts)/ holism (the whole); chaos/harmony; polemism (struggle)/harmonicism; monistic materialistic/pluralism (cf. Lyubishchev 1982).

It is fascinating to study this foundation of theories in the natural sciences, acting as a basis for discussion in a discipline of humanities such as linguistics. Marrism, as can be understood in spite of the obscurity of many of its formulations, rests essentially on the same refusal to explain similarities by a common origin. Like Jakobson, the Marrists refuse the idea of separate development of languages after untying from the common trunk. Schleicher's genealogical tree is expressly referred to in both cases. ${ }^{3}$ Marr and Jakobson try to make comparisons and parallelisms between non-related languages, except that Jakobson seeks similarities in phonological order and Marr in semantic order.

Of course, when making comparisons, similarities and differences will always be found; it depends on what is being emphasized. For example, in his refusal of gradualism and the assertion of the leap theory ('skachki'), Marr is closer to the counter-programme than Jakobson. The latter, however, is not always very clear as to its principles: for him, languages sometimes evolve by gradual convergence, sometimes by sudden leaps (cf. Jakobson 1931). Still, like Berg, both of them refuse genetic closure.

3 On the comparison between Eurasianists and Marrists by the refusal of inherited resemblances, cf. Sériot 2000. 


\section{Laws, types and forms}

We have seen how the notion of nomogenesis influenced certain Russian intellectuals of the interwar period. Two other unavoidable notions, with such a long and complicated history that we shall only recall some of their manifestations in the counter-programme in Russia, are to be examined: form and type.

Vladimir Propp is widely known in the West as the father of narratology, ${ }^{4}$ and his theories are taught in secondary schools. Yet it seems a bit hasty to claim this direct legacy. Propp's Morphology of the Tale (Propp 1928) uses, in my opinion, the notion of 'morphology' in a sense that is not structural, but organic, in relation to romantic biology and Naturphilosophie: morphology as "Essence" is capable of transformations from a plan, or type. ${ }^{5}$ It is interesting to note that each chapter of the book is preceded by an epigraph by Goethe, which has disappeared from the English translation (Propp 1958, 1968), although it was published on the initiative of Jakobson. It is true that the French translation (Propp 1970), which scrupulously preserved these epigraphs, did not give rise to any comments in this regard.

Goethe, in his morphology, or Formenlehre, followed a very different line from what Darwin would do later. The latter saw the appearance of new species in accidental variations. These variations are random; they are made without following a determined direction, and they suffice to explain the variety of organic forms. It is precisely the fact that form can be born from the formless and that a definite structure can appear from accidental variations, which is refuted by those who follow Goethe's and Cuvier's type theory: for Goethe, metamorphosis does not change an organic type into another, it can only lead to new formations within the same type (cf. Cassirer 1945: 105).

According to Cuvier's theory of organic types, ${ }^{6}$ living beings are constructed according to a very small number of unique plans, which constitute autonomous principles of morphological explanation, distinct from those based on the conditions of existence and environment. There can be no relationship between the different types.

In the theory of history, the theory of types is particularly well represented by the generation of the late Slavophiles of the years 1860-1880 (Nikolaj Danilevskij, Nikolaj Strahov), who developed a historical-cultural morphology in which the Slavic world and the "Romano-Germanic" world were perceived as different historicalcultural types, falling within different morphological histories (cf. Gasparov 1987: 53). These types are fundamentally distinct and invariable. Moreover, just as in Cuvier's

\footnotetext{
4 Cf. Brémont 1973, Part 1 "Propp's legacy”.

5 On this subject, cf. Gasparov 1998: 215.

6 On the contrary, for Étienne Geoffroy Saint Hilaire, the totality of organic beings follow a single plan. Goethe passionately followed the debate between Cuvier and Geoffroy Saint Hilaire in Paris in July 1830.
} 
branchings, which Danilevskij admired very much, the conditions of existence and the systems of organization of each of these historical-cultural types make historical experience, culture, philosophy and science integrally connected inside each type (cf. Todes 1989: 41).

Finally, the essentialism of this type theory consists in the fact that everyone embodies a particular "soul" or "destiny", which will never be repeated. A logical consequence is that intercultural relations have no meaning and are purely fortuitous. We can no longer speak of a human civilization, or of a single humanity, but only of a variety of cultures, of which we can at most study, like the pre-Darwinian botanist or zoologist, the morphology, that is to say the compared structures. Comparison thus serves to separate and not to unite. It must be clear that this morphological vision of the history of cultures is not unique to Russia: in Germany it can be found in Spengler, who also uses the notion of morphology of cultures. Let us recall that Jakobson had great admiration for Danilevskij, and he spoke of him as a "marvellous fruit" of Russian scientific culture (Jakobson 1929).

Morphology of cultures, understood as countable objects, is the basis of Troubetzkoy's ethnographic reasoning. Troubetzkoy distinguished true units (which are "organic"), and false units (which are "artificial"):

Two peoples who are close in their national character, living in contact with each other, and both led by genuine nationalists, will inevitably have very close cultures precisely because of such an exchange of acceptable cultural values by the two parts. But this cultural unity differs radically from the artificial unity which is the result of the tendencies to enslavement on the part of one of these two peoples. (Trubetskoj 1921: 83)

Perhaps more than elsewhere, Platonic essentialism was opposed in Russia in the 19th and 20th centuries to analytical thought and to what is called populationism in biology, which consists in considering animal species not as types, but as sets of individuals. It is a modern avatar of the medieval quarrel of the realists and the nominalists. Essentialist thought is based on the apparent evidence of the notions of discontinuity, of invariance, of "types". The basis of this type of thought, of Platonic origin, is geometry: any triangle, whatever the length of its sides, is always a triangle; it represents the idea of the triangle. There is no intermediate with other geometric figures, for example the rectangle. We are indeed in front of a discontinuous thought. But this spatial discontinuity is extended to temporal discontinuity: in an essentialist perspective, the origin of all change can only come from a leap, leading from the old essences to the new essences. ${ }^{7}$

7 On the critique of essentialism from the point of view of modern biology, cf. Mayr 1989: 67ff. 
An example of how difficult it is to abandon the typological-essentialist thought can be seen in the interpretation of the concept of phoneme as a "type of sound", especially in linguistic sociologism, which tries to rise from the level of the individual to that of the collective "fact". In the sociologism of the 1920 s, the individual is only a more or less approximate representative of the type represented by the language community (yazykovoj kollektiv). The corollary of this typological thinking is the downgrading of variation:

Not to mention the fact that in the observations of experimental phonetics the individual pronunciation facts threaten to obscure the object of study - the phoneme, or type of sound accepted as a norm within the limits of a language community, the most minute study of the laws governing the individual's linguistic activity and explaining the changes that occur there leaves unexplained the passage from the individual fact to the collective fact. (Shor 1926: 39)

On the definition of meaning as a social and not an individual fact:

In the external (sound) aspect of the word, this corresponds to the distinction between the ideal type of sound existing in the language community (the phoneme) and its approximate achievements in the individual speech of each member of this community. Observations show that two pronunciations of the same sound by the same individual are already different from one another; but the very fact of mutual understanding shows equally undoubtedly that there is something common between all these pronunciations. It is the theory of the phoneme, developed independently of one another by Baudouin de Courtenay and some French researchers, which makes it possible to distinguish this common form, or phoneme, which determines the activity of the individual and which is the property of the whole community. (Shor 1926: 66-67)

The theory of types, nevertheless, presents many avatars in linguistics in Russia. Thus, for the Marrists, a type of language, while distinguished by both formal and semantic specificities, is at the same time a "dialectic" step in the "unique glotogonic process":

[...] one might think that each language or group of languages of the same type represents the result of one system, shaped in another system, as if the development process had convenient bifurcation stations, different creative steps, between which one could only vegetate. In reality, these stations or these stages are crucial points, revolutions. They explode the established milieu, and open new ways, according to which a constitution [slozhenie] of a new type is gradually established; it is on these new paths that a divergence arises, the appearance of an antithesis next to the thesis, giving the outcome of the struggle a new solution in the mutation $[s d v i g]$ to the next bifurcation station. Creation is in the movement itself, not at the stages, as it is not at the beginning, but in the process of continuous 
accumulation and in the dynamics of material. (Marr, quoted, without indicating the source, in Serdyuchenko $1931: 175)$.

\section{Conclusion}

These few remarks give rise to a reflection on the long temporalities in the history of the humanities, as opposed to the notion of 'epistemological break' (Gaston Bachelard) or 'paradigm shift' (Thomas Kuhn).

There remains to be found the equivalent for reflection on space and the air of the place: a non-discontinuous vision of the limits between scientific cultures and national "traditions" in linguistics. ${ }^{8}$

\section{References}

Braginskaya, Nina V. 1998. Posleslovie ko 2-mu izdaniyu. In: Frejdenberg, Olga M., Mif $i$ literatura drevnosti. Moscow: Nauka, 744-765.

Bremont, Claude 1973. Logique du récit. Paris: Seuil.

Cassirer, Ernst 1945. Structuralism in modern linguistics. Word 1(2): 99-120.

Gasparov, Boris 1987. The ideological principles of Prague School phonology. In: Pomorska, Krystyna; Chodakowska, Elžbieta; McLean, Hugh; Vine, Brent (eds.), Language, Poetry and Poetics: The Generation of the 1890s: Jakobskon, Trubetzkoy, Majakovskij. Proceedings of the First Roman Jakobson Colloquium, at the Massachusetts Institute of Technology, October 5-6, 1984. Berlin: Mouton De Gruyter, 49-78.

- 1998. V poiskah "drugogo" (frantsuzskaya i vostochno-evropejskaya semiotika na rubezhe 1970-h godov). In: Neklyudov, Sergej (ed.), Moskovsko-tartuskaya semioticheskaya shkola: Istoriya, vospominaniya, razmyshleniya. Moscow: Yazyki russkoj kul'tury, 213-236.

Jakobson, Roman 1929. Über die heutigen Voraussetzungen der russischen Slavistik. Slavische Rundschau (Prague) 1: 629-646.

- 1931. K harakteristike evrazijskogo yazykovogo soyuza. Paris: Izdatel'stvo evrazijtsev.

Lyubishchev, Aleksandr A. 1982. Problemy formy, sistematiki i evolyutsii organizmov. Moscow: Nauka.

Mayr, Ernst 1982. The Growth of Biological Thought: Diversity, Evolution and Inheritance. Cambridge: The Belknap Press of Harvard University Press.

Propp, Vladimir 1928. Morfologiya skazki. Leningrad: Akademiya.

- 1958. Morphology of the Folk Tale. (Pirkova-Jakobson, Svatava, ed.; Scott, Laurence, trans.) Bloomington: Indiana University Press.

- 1968. Morphology of the Folk Tale. (2nd ed.) (Wagner, Louis A., ed.; Dundes, Alan, intr.; Scott, Laurence, trans.) Austin: University of Texas Press.

- 1970. Morphologie du conte. (Derrida, Marguerite, trans.) Paris: Seuil.

8 Acknowledgments. This paper was written as part of a project funded by the Russian Science Foundation (Grant 16-18-02042) and carried out at St. Petersburg State University. 
Schleicher, August 1863. Die Darwinsche Theorie und die Sprachwissenschaft. Weimar: Böhlau. Serdyuchenko G. 1931: Staroe i novoe v nauke o yazyke. Na pod'eme 4: 156-175.

Sériot, Patrick 2000. Eurasistes et marristes. In: Auroux, Sylvain (ed.), Histoire des idées linguistiques 3. Liège: Mardaga, 473-497.

- 2014. Structure and the Whole. East, West and Non-Darwinian Biology in the Origins of Structural Linguistics. (Semiotics, Communication and Cognition 12.) Boston: De Gruyter Mouton.

Shor, Rozalija O. 1926. Krizis sovremennoj lingvistiki. Jafeticheskij sbornik 5: 32-71.

Todes, Daniel P. 1989. Darwin without Malthus: The Struggle for Existence in Russian Evolutionary Thought. New York: Oxford University Press.

Toman, Jindrich (ed.) 1994. Letters and Other Materials from the Moscow and Prague Linguistic Circles, 1912-1945. (Cahiers Roman Jakobson 1.) Ann Arbor: Michigan Slavic publications.

Trubetskoj (Troubetzkoy), Nikolaj S. 1921. Ob istinnom i lozhnom natsionalizme. Ishod $k$ Vostoku. Sofija, 71-85.

Velmezova, Ekaterina 2003. O. M. Frejdenberg, à la recherche d'une science intégale. In: Sériot, Patrick (ed.), Le discours sur la langue en URSS à l'époque stalinienne (épistémologie, philosophie, idéologie). Cahiers de l'ILSL 14: 265-280.

\section{Биология для лингвистов - препятствие или главный путь к построению концептов?}

Случаи обмена моделями, метафорами и аналогиями между лингвистикой и биологией хорошо известны, а книга Августа Шлейхера "Die Darwinsche Theorie und die Sprachwissenschaft” (1863) является характерным примером этого направления мысли. Тем не менее, существует и «встречный мейнстрим», который менее известен: ортогенез, эксплицитно антидарвинистская биологическая теория, последствия которого наблюдаются в истории советской лингвистики и в среде русских эмигрантовлингвистов. Тут важнейшими являются имена Николая Трубецкого и Романа Якобсона, если учесть, что они были в значительно мере инспирированы «морфологическим учением» Гете и «номогенезом» Льва Берга. Важным моментом является и спор между Жоржом Кювье и Этьенном Жоффруа Сент-Илером в 1830 году, подчеркивающий отличие русского и центрально-европейского структурализма от соссюровского.

\section{Bioloogia keeleteadlastele: takistus või kuninglik tee mõisteloome juurde?}

Mudelite, metafooride ja analoogiate vahetamine bioloogia ja lingvistika vahel on hästi tuntud ning August Schleicheri raamat "Die Darwinsche Theorie und die Sprachwissenschaft" (1863) on selle mõttesuuna tüüpilisi töid. Ometi on sellele oma "vastu-peavool", mida tuntakse vähem, kuid mida on äärmiselt huvitav jälgida: ortogonees, eksplitsiitselt antidarwinistlik bioloogiateooria, mille tagajärgi on põnev täheldada Nõukogude keeleteaduse lingvistikaideede ajaloos ja ka Vene emigrantlingvistide puhul maailmasõdade vahelisel perioodil. Siin on esmase tähtusega Nikolai Trubetskoi ja Roman Jakobsoni nimed, kui võtame arvesse, et nad said 
märgatava osa oma inspiratsioonist Goethe "vormiõpetusest” ja Lev Bergi "nomogeneesist". Oluline tähenduslik moment on ka väitlus Georges Cuvier’ ja Étienne Geoffroy Saint-Hilaire’i vahel 1830. aastal, kriipsutamaks alla Vene ja Kesk-Euroopa strukturalismi eripära, mis on äärmiselt erinev Saussure’i omast. 